responsibility is increased his job may become more of a strain.

What kind of strains are imposed upon the worker ? First, there is the nervous strain caused by the need of unremitting attention to signals of varying perceptability, often separated by long intervals. The less the physical activity of such a worker and the greater the number of indicators to be watched, the more the nervous tension to which he will be exposed. In these circumstances particular importance will be attached to working conditions, such as temperature, sound-proofing, lighting, and the position of the operator and the machines. By preventing the operator from communicating with others, automated work tends to isolate him both physically and mentally. This feeling of isolation may be heightened by the background noise made by the machines.

In addition to its direct effects upon the workers' mental health, automation will undoubtedly have indirect social consequences. Families may, for example, be affected by the increased mobility of labour. The most serious difficulties indirectly affecting mental health are, however, liable to arise in connexion with the organization of the work itself. If automation calls for more shift work (as appears likely), this will certainly be opposed by the workers and their families.

Automation may provide certain satisfactions; for example, in an entirely automated plant, each operator becomes more or less his own master; the gap lessens between the factory worker and the office worker, and changes of occupation in middle age should be easier.

Efforts to mitigate the harmful effects of automation on mental health should be based on informa. tion and education. Education will be all the more effective if it is directed primarily towards those in key positions, that is to say, managers, engineers, trade-union leaders and the medical profession, particularly works doctors.

\title{
EMPLOYMENT OF WOMEN IN BRITAIN
}

$\mathrm{T}$ HE Institute of Personnel Management has published under the title "Working Wives" a survey of facts and opinions concerning the gainful employment of married women in Britain carried out in co-operation with Mass Observation, Ltd., by Viola Klein during the autumn months of 1957, when out of $12,820,000$ married women in Great Britain nearly 4 million were gainfully employed (Occasional Papers, No. 15. Pp. 63 . London: Institute of Personnel Management, 1960. 7s. 6d.). Thus, in about one out of every three households the wife contributes by her earnings to the family income, but the apparent steep rise in the employment of married women since 1951 is due to the Population Census seriously underrating the number of married women in employment, particularly part-time. The outstanding impression gained by the survey is that women's lives to-day are dominated as much as ever by their role-actual or expected-as wives and mothers, and all other occupations are subordinated to their responsibility for home and family. The growth in the number of married women going out to work is due to the smaller size of their families and the general reduction in housework through the modernization of household techniques, combined with a striving to improve their standards of living. It is not widely assumed that married women should have jobs, although among the more highly educated single women in the sample nearly one third wished to continue their careers after marriage ; this is nearly double the percentage in the next occupational group of women willing to continue in employment not merely temporary. The taking up of employment by married women appears to result from unforeseen though not unforeseeable cireumstances, and men appear to be loss conservative in their outlook in these matters than they are usually assumed to be.

Slightly more than one half the married women in employment have part-time jobs, which may be in the region of 4-30 hr. per week. The sample also showed that two-thirds of the women in part-time employment are engaged in unskilled or semi-skilled work, and that shorthand typing is the occupation least likely to offer any scope for the married woman who wishes to supplement her income by part-time employment. In some smaller occupational groups, such as teachers, nurses, social workers, a shortage of trained staff has opened the doors to part-time employees, and though the problems involved have not yet received the attention they deserve, more opportunities may well be offered here in the future for married women to combine a career with having a family. Women, in fact, it is concluded, are an essential and distinctive part of our man-power resources.

\section{EXPLORATIONS OF THE GALÁPAGOS ISLANDS}

$\mathrm{T}$ HE Galápagos Islands have recently attracted widespread attention as a result of the Darwin centenary and the measures at present being taken to preserve and study their flora and fauna. The Galápagos Islands have been one of the principal fields of endeavour of the California Academy of Sciences since its first expedition there during 1905-6, and its collections from the archipelago are unsurpassed. It is therefore appropriate that the Academy should publish a short history of the islands by the late Joseph Richard Slevin, for more than fifty- three years associated with its Department of Herpetology, and a member of the original expedition, who for half a century maintained an active interest in the islands and published a number of scientific and popular papers about them (Occasional Papers of the California Academy of Sciences. No. 25: The Galápagos Islands : a History of their Exploration. By Joseph Richard Slevin. Pp. $x+150$. San Francisco : California Academy of Sciences, 1959).

This publication gives a description of the islands, their geology, climate, and fauna, but it is mainly 